with one financed by the expatriate's US institution, for some other purpose, or because he, in any case, has to return for some family reason. Even an invitation to give a lectare, which cannot be accepted for financial reasons, would serve to encourage an eventual return home. It does at least indicate to the expatriate that he has not boon written off as dead.

I have had some indications that expatriates who wishod to return have sometimes felt that thoy had received a somowhat cold reception from the British interviewing authorities in Washington. It is, of course, true that the Joint Interviewing Board, contrary to popular mythology, does not have the reversal of the brain drain as its primary function. Two students of mine returned a few years ago from one of these interviews in a vory despondent frame of mind because they thought they had been confronted by a take it or leave it attitude. Their cormments wero not as caustic and unflattering as those of eight returned brain drainees, now working for Imperial Chemical Industries, which are quoted in an article by Kay Evans in The Observer of October 22. Had thore not been an overriding reason which made a return to Britain imperative, my students might well have stayed in the United States or Canada and might have refused the job eventually offered thom by the JIB. I believe that efforts are being made to remedy this situation. I have before me an advertisement in an American scientific journal issued by tho British recruiting authorities in Washington and Ottawa. It is informative and business-like, but again I miss any sign of enthusiasm for the recovery of the lost shoop. The expatriate must regard himself only as a "candidate" for a post at home. He may well ask himself why he should trouble to do so if the Amoricans are asking him to stay on with them. The advertisement may well attract a response only from those who have found themselves to be misfits over here.

My proposal to those at home, if they want to reverse the brain drain, is: Show an interest in the expatriate scientist or engineer, tell him that he would be welcomed back and ask him to roturn! You may well be surprised at the response you will receive. This conclusion $I$ had reached some years ago. I was delighted to see, again in the October 22 articlo in The Observer, that Imperial Chemical Industries had been successfully practising the method for some time.

Director,

G. C. MoVrTtre

University of Illinois Observatory,

Urbana,

Tllinois, USA.

\section{Organization at Ministry of Technology}

Srr,-Your issue of November 25 reported a speech by Sir Richard Clarke, Permanent Secretary, Ministry of Technology, to a joint meeting of the Royal Institute of Public Administration and the British Institute of Management (Nature, 216, 745; 1967). Sir Richard compared the chances of able administrators, engineers, scientists and other specialists, getting to the top posts in his ministry relatively young, and concludod that the prospects were probably the same on all ladders. This is a seriously misleading statement. The fact is that in the Ministry of Technology able engineers and scientists havo markedly inferior prospects to those of administrators of getting to the top. In this respect, this ministry is no different from the rest of the Civil Service.

There are 150 administrators in the Ministry of Tochnology of whom 22 are on salaries of $\$ 5,000$ or more, that is 14.7 per cent. There are 1,985 scientific officers of whom 40 are on salaries at this level, that is 2.02 per cent. The prospects for professional engineers are much worse; there are about 1,100 qualified professional engineers of whom only 3 are at this salary level, which is much less than 1 per cont.
For the Civil Service as a whole, the comparative percentages of those on $£ 5,000$ or more are: administrators, 15.3 per cent; scientists, 2.3 per cent; professional ongineers, 0.2 per cent.

The explanation is simple. At tho highest levols in tho Civil Service, and in spite of the changing role of government, management and administration are still almost exclusively the monopoly of tho administrative class. Although departments differ in size, function and complexity, one thing rernains constant: an administrative Permanont Sccrotary is at the head and ho has ono or more deputy secretaries, according to the size of the department, and a varying number of under secretaries, all of whom are members of tho lay administrative class. Out of 36 posts at Permanent Secretary level, 33 are filled by members of the administrative class. This class is relatively small and consequontly tho career pattorn referred to above is produced. As long as advice to Ministers, policy determination, and the control of the governmental machine are vostod in the administrative class, the opportunities of advancement for scientists and engineers to the very top posts will be seriously restricted.

The Jones Committee on the brain drain said that last year Britain suffered a net loss of 1,870 engineers and technologists, aged chiefly between 25 and 35 , which is a third of our avorage annual output, and that the trond was increasing. It forecast disastrous consequences for British industry and the economy within ten to twenty years if it were to continue at the prosont rate.

The Prime Minister has laid the chief blame on the British industrial system, which, he has said, did not put a proper valuation on such pooplo. The Treasury has overall responsibility for career management in the Civil Service, but, in spite of all that has been said by its political mastors about the nood to improve both the status and the responsibilities of engineers and scientists, it regards comparisons between administrators on the one hand and profossional engineers and scientists on the other as having neither validity nor relevance. This Institution has tried repeatedly to persuade the Civil Sorvico to romody this situation but without avail. Statements and pledges have been made by various Governments from time to time which indicate, in the cloarest possible way, the need for major reform. The clearest pledge on the question of parity as between the administrative and the professional civil servant was given by Lord Cherwell, speaking in the House of Lords on behalf of the Government, as far back as 1943. He said: "I must frunkly admit that the Civil Service has not hitherto shown duo regard for the contribution which scientists are making to the nation's welfare. I am glad to be able to say in answer to Lord McGowan's question that this matter has now been reviewed, and that an investigation has been in progress to mako sure that the conditions of service, pay and prospects of Government scientific employees compare favourably with those on the administrative side of Government work, so that, among other things, interchange may in suitable ceses be made easier. I hope that a definite announcoment that these reforms are to be put into effect may bo made bofore long." There is great rigidity in the nineteenth century class "casto" system in the Civil Service, which cannot be modernized to fit purposive government without causing trouble. I leave it to your readers to judge for themselves the extent to which the Civil Service has implemented the long outstanding Government pledge which I have quoted.

Yours faithfully,

T. H. Profiț

Deputy General Secretary.

The Institution of Professional Civil Sorvants,

Northumberland Stroot,

Tondon, WC2. 